\title{
Virtual water flow and water footprint as optimizer of water resource management in the state of Ceará, Brazil
}

Fluxo de água virtual e pegada hídrica como otimizadores da gestão dos recursos hídricos no estado do Ceará, Brasil Ivana Sampaio Leite ${ }^{1}\left(\mathbb{D}\right.$, Rodolfo José Sabiá $^{1}(\mathbb{0})$, Andrezza Pereira Matos $^{1}$ (), Camila Cavalcante Silva ${ }^{1}$

\begin{abstract}
A B S T R A C T
The water exported indirectly by sending products to other countries, or vice versa, is called a virtual water flow and this can be measured through water footprint (WF) calculations, which represent the embedded water needed to manufacture a product. This present study aims to analyze the virtual water flow and the WF of the main products exported by municipalities in the state of Ceará in the year 2019, in order to enhance the management of the state's water resources. Analytical hierarchy process (AHP), the most commonly used multicriteria decision-making method in the world, was used to determine which product is more sustainably produced by the municipalities of Ceará, with the criteria: WF, price, and volume exported. The alternatives are at least two of the seven categories of products exported by the state where the "fruit or vegetable juices" class was preferred as the most sustainable. It was found that most cities in the state that export agricultural products use only one basin, which can lead to very low reservoir levels, while the other hydrographic basins in the state are underused. It is worth noting that the Metropolitan Basin concentrates on 11 out of 32 municipalities that export abroad and that it is responsible for supplying more than 4,074,730 inhabitants, according to Brazilian Institute of Geography and Statistics (IBGE, 2019).
\end{abstract}

Keywords: water management; water resources; analytical hierarchy process; hydrographic basins.

\section{RE S U M O}

A água exportada indiretamente pelo envio de produtos a outros países, ou vice versa, chama-se fluxo de água virtual e pode ser mensurado por cálculos de pegada hídrica, que representam a água embutida necessária para a fabricação de um produto. O presente estudo teve o objetivo de analisar o fluxo de água virtual e a pegada hídrica dos principais produtos exportados por municípios do estado do Ceará no ano de 2019, a fim de potencializar o gerenciamento dos recursos hídricos do estado. Utilizouse o analytical hierarchy process (AHP), método de tomada de decisão multicritério mais usado no mundo, aqui escolhido para determinar qual o produto mais sustentável produzido pelos municípios do Ceará, com os critérios: pegada hídrica, preço e volume exportado. As alternativas são pelo menos duas das sete categorias de produtos exportados pelo estado, e a classe de "sucos de frutas ou vegetais" foi preferida como a mais sustentável. Constatou-se que a maioria das cidades do estado que exportam produtos de origem agropecuária faz uso de apenas uma bacia, o que pode acarretar níveis muito baixos de reservatório, enquanto as outras bacias hidrográficas do estado são subusadas. Vale a pena salientar que a Bacia Metropolitana concentra 11 de 32 municípios que exportam para o exterior e é responsável pelo abastecimento de mais de 4.074.730 habitantes, segundo o Instituto Brasileiro de Geografia e Estatística (2019).

Palavras-chave: gerenciamento da água; recursos hídricos; analytical hierarchy process; bacias hidrográficas.

\footnotetext{
${ }^{1}$ Universidade Regional do Cariri - Juazeiro do Norte (CE), Brazil.

Correspondence address: Ivana Sampaio Leite - Universidade Regional do Cariri - Avenida Leão Sampaio, 107 - Lagoa Seca - CEP: $63041-145$ Juazeiro do Norte (CE), Brazil. E-mail: gabinete@urca.br

Conflicts of interest: the authors declare that there are no conflicts of interest.
}

Funding: Projeto Universal Conselho Nacional de Desenvolvimento Científico e Tecnológico (CNPq), edital no. 01/2016.

Received on: 12/10/2020. Accepted on: 07/13/2021.

https://doi.org/10.5327/Z217694781003 


\section{Introduction}

Water is the most important natural resource for human, playing a fundamental role in activities of daily living. The indiscriminate uses of water for different purposes began to generate conflicts due to its false abundance. Currently, the approach to limiting water resources has been highlighted (Hoekstra and Chapagain, 2007). Furthermore, the total volume of fresh water that is used to produce the goods and services consumed by the individual or the community is defined as a water footprint (WF) (Hoekstra et al., 2011).

In this way, a country's WF can be directly determined by other factors, such as the volume of consumption (related to gross national income), the consumption pattern (e.g., high versus low meat consumption), the climate (crop growth conditions), and agricultural practice (efficient water use) (Hoekstra and Chapagain, 2007). Therefore, virtual water is described as an instrument for the management of water resources, serving as an indirect measure of the water consumed by a good, product, or service (Guimarães and Xavier, 2008).

It is important to emphasize the concept of virtual water, which refers to the amount of water incorporated in a certain product. We use the term virtual water in the international (or interregional) context of virtual water flow; therefore, when a country or region exports or imports a product, it is exporting or importing water in a virtual way (Hoekstra et al., 2011).

In this case, we can speak in a general way about flows or the trade in virtual water. The northeast region of the country is characterized by high temperatures, high evaporations, and scarcity of rain. There is a significant discernment when the WF is compared with the current capacity of these reservoirs, that is, with the amount of water in the hydrographic basins quite reduced in relation to their total capacities. The state of Ceará has the fourth territorial extension of the northeast region and is the 17th among Brazilian states in terms of territorial surface. Ceará borders the states of Pernambuco, Rio Grande do Norte, Paraíba, and Piauí. In addition, it has 184 municipalities and 20 administrative microregions, especially the Metropolitan Regions of Fortaleza, with 19 cities, and Cariri, with 9 cities (IPECE, 2010). The 2019 Brazilian Institute of Geography and Statistics (IBGE) data indicate a territorial area of $148,894,441 \mathrm{~km}^{2}$ and an estimated population of $9,132,078$ people.

The National Water Resources Council is responsible for promoting the planning and management of water resources and their respective hydrographic basins. Hydrographic Basin is an area where all the rain that falls drains, by streams and secondary rivers, to the same main river, located in a lower point of the landscape being separated from the other Basins by a dividing line called water divider (COGERH, 2018).

In this case, according to the State Water Resources Plan (ANA, 2018), the state of Ceará consists of 155 dams and 12 hydrographic basins, which are classified as Coast, High Jaguaribe, Coreaú, Metropolitans, Ibiapaba Hill, Medium Jaguaribe, Salgado, Acaraú, Banabuiú, Crateús Hinterland, Curu, and Low Jaguaribe, comprising a volume of
$18,617 \mathrm{hm}^{3}$ (FUNCEME, 2019). Furthermore, the volume of the basins has great relevance to calculate the volume of water taken from the state basins for agricultural production using the WF calculation. It is important to note that the volume used in the hydrographic basins varies according to the period under analysis for the calculation of the WF, since the WF depends on the volume of water incorporated, the climatic conditions, and the geographical position in question.

Barreto et al. (2010) and Fiel et al. (2017) highlighted that water is used as a strategy in conflict management and environmental protection, which would justify the establishment of hydrographic basin management through the Hydrographic Basin Committees (CBHs), as it seeks a balance between human demand and consumption, animal intake, and irrigation.

The presence of CBHs in Brazil arises from the far reaching of inhabitants, who need a high amount of water for human and animal consumption, food production, industrial products, recreation, and so on. It creates a very high demand for it, causing water scarcity, in addition to degradation through solid and liquid organic waste, chemicals, and soil erosion, among others. Due to this scarcity of water and lack of water quality, there might be stagnation and even a drop in the economic situation (Fiel et al., 2017).

A survey conducted using water resources as a tool aims to ensure that the quality of the water is compatible with its demand, the framing of the waters, in the hydrographic basins of rivers that are part of the domain of the Union. It also aims to identify the importance of the framework for planning water quality, as well as the difficulties and possibilities of its implementation. An analysis of the most recent plans of the nine basins with constituted committees was made to seek aspects related to the framework and to compose the study method; electronic questionnaires were applied to the committees of the analyzed basins and also to the National Water Agency to diagnose the understanding of the research focus. Based on the results, it was possible to identify and observe the absence of framing according to the current regulation, namely, CONAMA Resolution $n^{\circ} 357 / 05$, in all the situations (Souza and Pizella, 2021).

Kaplowitz and Witter (2008), Mahmoud et al. (2011), and Fiel et al. (2017) pointed out that, with the extent of water scarcity putting pressure on existing water management and distribution systems, it is essential to identify and analyze the factors that can change consumption management for efficient management, including river basins.

The analytical hierarchy process (AHP) is the most commonly used multicriteria decision-making method in the world. In this perspective, for Barker and Zabinsky (2010), this method satisfies the selection of the criteria suggested by it, including adequacy, ease of use, and validation of its results. The AHP method is based on three stages: building hierarchies through structuring the problem, establishing weights for criteria and preference for alternatives, and analyzing the results (Tramarico et al., 2012). In contrast, the AHP turns comparisons, often empirical, into numerical values that are processed and compared. 
The weight of each of the factors allows the assessment of each of the elements within the defined hierarchy. This ability to convert empirical data into mathematical models is the main differential of AHP in relation to other comparative techniques (Vargas, 2010). This method represents an improvement in making decisions by managers, who often depend on their experiences or feelings (Silva et al., 2015).

In this way, it can be said that a multicriteria decision problem consists of a situation that there are at least two alternatives of action to choose and that choice is driven by the desire to meet multiple objectives, often conflicting with each other. These objectives are associated with the consequences of choosing the alternative to be followed and variables that represent them and allow the evaluation of each alternative, based on each objective. These variables can be called criteria, attributes, or dimensions (Almeida, 2013).

This study was developed with the objective of analyzing the virtual water flow and the WF of the main products exported by municipalities in the state of Ceará, in order to enhance the management of the state's water resources.

The use of water by culture in the municipalities of Ceará was quantified, calculating the WF and the virtual water flow of the main products exported by the state of Ceará. It was also verified the integrated planning of the hydrographic basins of the state in order to assess the impacts of the WF in the hydrographic basins of Ceará, developing a methodology as a solution through decision-making methods to define the best product to be exported by each municipality in the state of Ceará.

\section{Materials and methods}

For this study, we used the exploratory research method, composing a qualitative and quantitative approach, with the development of a bibliographic character, since it succeeded in reviewing articles. In order to emphasize the study, AHP with the multicriteria decision maker was used as attributing continuity to the development of the research. In addition, histogram, which is a column chart used in statistics, is used. It consists of several adjacent rectangles, representing the frequency table with loss of information (values grouped by classes) of a set of values. On the horizontal scale, class intervals are marked, and each interval is the basis of each rectangle or bar; on the vertical scale, the heights of the rectangles or bars are marked, representing the respective absolute frequencies of the classes (Lopes, 1999; Kurokawa and Bornia, 2002).

\section{Study area}

The state of Ceará, the target of the research, is highlighted in the agribusiness issue, mainly in the agricultural sector. Given this, the use of water, directly and indirectly, is part of the entire agricultural production process in the state where significant advances have been made in relation to the use of water resources.

\section{Calculation of the export water footprint}

The calculated exported WF corresponds to the volume of water exported indirectly from the state of Ceará to other countries, where the exported WF of Ceará is from a geographically delimited region. In addition, the exported WF is related to basic, manufactured, and semi-manufactured products exported by the northeast region. The products exported by Ceará were separated from the entire agricultural sector, separating the quantity (in ton) by the municipalities of the state of Ceará, of each corresponding product. Subsequently, the collection of all products exported by state, obtained the WF exported from the analyzed region, as shown in Equation 1:

$P H_{\text {EXPORTADA }}=P H_{\text {BÁSICOS }}+P H_{\text {SEMIMANUFATURADOS }}+P H_{\text {MANUFATURADOS }}$
$P H_{\text {EXPORTADA }}=\left(Q_{P B} * P H_{P R O D}\right)+\left(Q_{P S} * P H_{P R O D}\right)+\left(Q_{P M} * P H_{P R O D}\right)$

Where:

$P H_{\text {EXPORTADA }}=$ exported $\mathrm{WF}$, in $\mathrm{m}^{3} /$ year;

$P H_{B A S I C O S}=$ exported $\mathrm{WF}$, in $\mathrm{m}^{3} /$ year;

$\mathrm{PH}_{\text {SEMIMANUFATURADOS }}=\mathrm{WF}$ exported from semi-manufactured products, in $\mathrm{m}^{3} /$ year;

$P H_{\text {MANUFATURADOS }}=\mathrm{WF}$ exported from manufactured products, in $\mathrm{m}^{3} /$ year;

$Q_{P B}=$ quantity of the respective basic product, in $\mathrm{kg}$;

$Q_{P S}=$ quantity of the respective semi-manufactured product, in $\mathrm{kg}$;

$Q_{P M}=$ quantity of the respective manufactured product, in $\mathrm{kg}$;

$P H_{P R O D}=\mathrm{WF}$ of a product, in $1 / \mathrm{kg}$.

All WF data exposed in this article were taken from Hoesktra et al. (2011) with the analysis made for Brazil, as there are no studies of the specific region.

\section{Analytical hierarchy process}

AHP methodology allows us to determine which alternative is the most consistent with our criteria following the level of importance we determine. The priority is a score that classifies the importance of the alternative or criterion in the decision, comparisons are made pair by pair, using the fundamental scale with values ranging from 1 to 9 , which is called Satty Fundamental Scale, as shown in Table 1.

Furthermore, when using the method, we divide and define the levels according to the AHP methodology in order to determine the most sustainable product produced by the municipalities of Ceará; in the second level, we defined the three criteria: WF, price, and volume, as shown in Table 2.

Finally, the alternatives, which we define as the main products exported from Ceará. Based on the definition of the main objective, criteria, and alternatives, hierarchical modeling was developed to guide the application of the AHP (Figure 1). 
Table 1 - Analytical hierarchy process comparison scale.

\begin{tabular}{|c|c|}
\hline Score (weight) & Definition \\
\hline 1 & Equally important \\
\hline 3 & Weak importance \\
\hline 5 & Strong importance \\
\hline 7 & Very strong importance \\
\hline 9 & Absolute importance \\
\hline $2,4,6,8$ & Intermediate values \\
\hline
\end{tabular}

Source: adapted from Saaty (1997).

Table 2 - Criteria used in analytical hierarchy process.

\begin{tabular}{|c|c|}
\hline Criteria & Function \\
\hline $\begin{array}{l}\text { Water } \\
\text { Footprint }\end{array}$ & $\begin{array}{l}\text { Quantitative criterion, with unit of measurement } \mathrm{L} / \mathrm{kg} \text {, which } \\
\text { demonstrates the direct and indirect quantity for the production } \\
\text { of a certain food, and with the objective of minimizing. }\end{array}$ \\
\hline Price & $\begin{array}{l}\text { Quantitative criterion, with unit in US\$, and with the } \\
\text { objective of maximizing. }\end{array}$ \\
\hline Volume & Quantitative criterion, of unit in $\mathrm{m}^{3}$, the objective is to maximize. \\
\hline
\end{tabular}

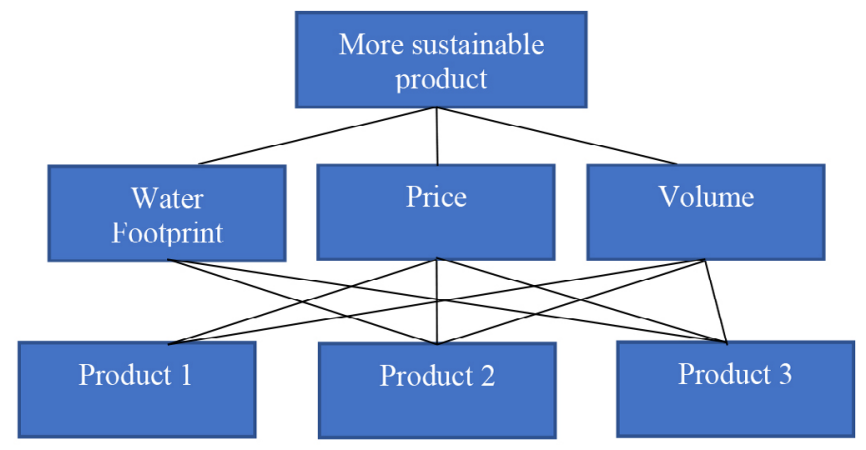

Figure 1 - Hierarchical model used in the problem.

\section{Results}

Through the online platform Comex Stat, aggregated to Comex Vis official Brazilian system for consulting foreign trade data, a survey was carried out of the products of agricultural origin that the state of Ceará exports and are organized into categories, as shown in Table 2.

Information on volume exported by product category all over Brazil and the percentage of participation by state was also available. Based on this information, the calculations of the participation in tons of the state of Ceará were carried out, and the equivalent price for the exports of each section was also extracted from the platform, in dollar and Free On Board (FOB), all for 2019 (Table 3).
The WF was also determined for the main exported products; for each category, the footprint that corresponds to the main product produced, in volume, of each section was used. The categories "shoes" and "leather" were used for calculating WF of the leather; "fillets and other frozen, fresh or chilled fish meats" for the lobster; "non-oil fruits and nuts, fresh or dried" used an average of cashew, melon, banana, guava, mango, and papaya footprints. For "other animal or vegetable fats and oils, processed, waxes, mixtures, or non-food preparations," the footprint of natural honey was used. The juice and cotton section made use of their corresponding footprints (Table 4).

In the subsequent stage, a study was carried out of the municipalities in the state of Ceará that export to other countries and their respective hydrographic basins. As in this work we are only attending to products of agricultural origin, a filter was made where we remove cities that export at least one product that is included in the seven types of categories mentioned above (Table 5).

The correlation of the seven categories of agricultural products exported by Ceará with the municipalities that export them is shown in Table 6.

There are 12 basins found in the state of Ceará, as mentioned in the methodology. In order to analyze where the water consumption required for each product category comes from, seven maps were elaborated that show which hydrographic basins the water resource is being used to produce the goods for export.

The sector that produces footwear makes greater use of the Metropolitan Basin, with four of 15 cities being supplied. It is the category that most exports its products. It is then noted when analyzing the map that the northern region of the state has a higher water consumption by the basins (Figure 2).

The "leather" category, the most used basin in this sector is the Metropolitan, with a total of four of seven municipalities. In other words, $57.14 \%$ of the water resource comes from just one basin. The concentration of the use of this resource is still found in the northern region of the map (Figure 3).

In the category of "fillets or other frozen, fresh or chilled fish meat," the withdrawal of water is concentrated on the coast of the state, not least because the products of this category are meat of fish, caught in the sea (Figure 4).

The second category that exports the most is "fruit and nuts, nonoil, fresh or dried," with a total of 13 cities. This sector has a more decentralized distribution, with exporting municipalities present in both the north, east, and south of the state of Ceará. This sector makes use of the waters of a greater range of hydrographic basins, although $38.46 \%$ of water use in this category comes from only one basin, the Metropolitan Basin (Figure 5).

There are eight municipalities that export the category of "other animal or vegetable fats and oils, processed, waxes, mixtures or non-food preparations," with five corresponding to $62.5 \%$ of water withdrawal 
Table 3 - Main products exported by the state of Ceará in 2019.

\begin{tabular}{|c|c|c|c|c|}
\hline Product category & Tons (total Brazil) & Participation Ceará (\%) & Tons Ceará & Price in millions (US\$) \\
\hline Leather & $471,839.00$ & 4.52 & $21,327.13$ & 52.3 \\
\hline Fillets or other frozen, fresh or chilled meat & $193,269.70$ & 0.94 & $1,816.73$ & 4.53 \\
\hline Dried fruit and nuts, fresh or dried & $947,709.10$ & 17.40 & $164,901.38$ & 161 \\
\hline Fruit juices or vegetables & $2,363,728$ & 2.73 & $64,529.77$ & 57.6 \\
\hline Cotton fabric, screens (not including tapes or specials) & 19,846 & 26.60 & $5,279.04$ & 32 \\
\hline
\end{tabular}

Source: Brasil (2020).

Table 4 - Volume of products exported in 2019 and their water footprints.

\begin{tabular}{|c|c|c|c|}
\hline Product category & Tons annual total & Water footprint( $\mathrm{m}^{3} /$ tons $)$ & Annual water footprint ( $\mathrm{m}^{3} /$ year) \\
\hline Leather & $21,327.13$ & 18,770 & $400,310,230.1$ \\
\hline Fillets or other frozen, fresh or chilled meat & $1,816.73$ & 4,325 & $7,857,357.25$ \\
\hline Dried fruit and nuts, fresh or dried & $164,901.38$ & $3,500.6$ & $577,253,770.8$ \\
\hline Fruit juices or vegetables & $64,529.77$ & 1,018 & $65,691,305.86$ \\
\hline Cotton fabric, screens (not including tapes or specials) & $5,279.04$ & 9,982 & $52,695,377.28$ \\
\hline
\end{tabular}

Source: Hoekstra et al. (2011) and Brasil (2020).

from the Metropolitan Basin. And the concentration of cities by area is in the north of the state (Figure 6).

In the category of "fruit or vegetable juices," as shown in Figure 7, the northern and eastern regions of the state concentrate exporting cities, although the water use required by cities comes from a greater variety of river basins.

The category "cotton fabric, canvas (not including as ribbons or specials)" has fewer cities exporting and all make use of the Metropoli$\tan$ Basin, so $100 \%$ of the cotton fabric sector requires water from only one hydrographic basin (Figure 8).

\section{Discussion}

According to Falkenmark and Molden (2008), the economic growth of the population implies an increase in the demand for water and food. The Southeast region of Brazil faces the main problems of water resources related to the scarcity due to pollution and excessive use of water in urban and industrialized areas, its conflicts of use, and the constant flooding (Porto et al., 1999). Barreto et al. (2010) added that the association between water scarcity and disordered economic exploitation causes soil degradation and desertification, in addition to a significant reduction of plant and animal species (Fiel et al., 2017).

With the application of AHP methodology to Excel, the most sustainable product of each municipality for export was analyzed, depending on WF, price, and volume exported, corresponding to the year 2019. The most important criterion is the WF, followed by price and volume (Table 7).

A total of 32 municipalities in Ceará are exporters of agricultural products; of these, an AHP analysis was carried out for decision-making in 21 cities, as the others exported only one type of product category, not making the method feasible. After an initial structuring of the problem, priorities are calculated based on pairwise comparisons, arranged in matrices of order of magnitude from $2 \times 2$ to $6 \times 6$. The alternatives were the seven categories of products exported by the state, the largest exporting city being the capital, Fortaleza, which exports six of the seven categories.

From the results obtained in the decision-making, a table with the AHP values organized by product category and by the cities that export more than one category is created, with total decimal number of 
Table 5 - Products exported by each municipality and its hydrographic basins.

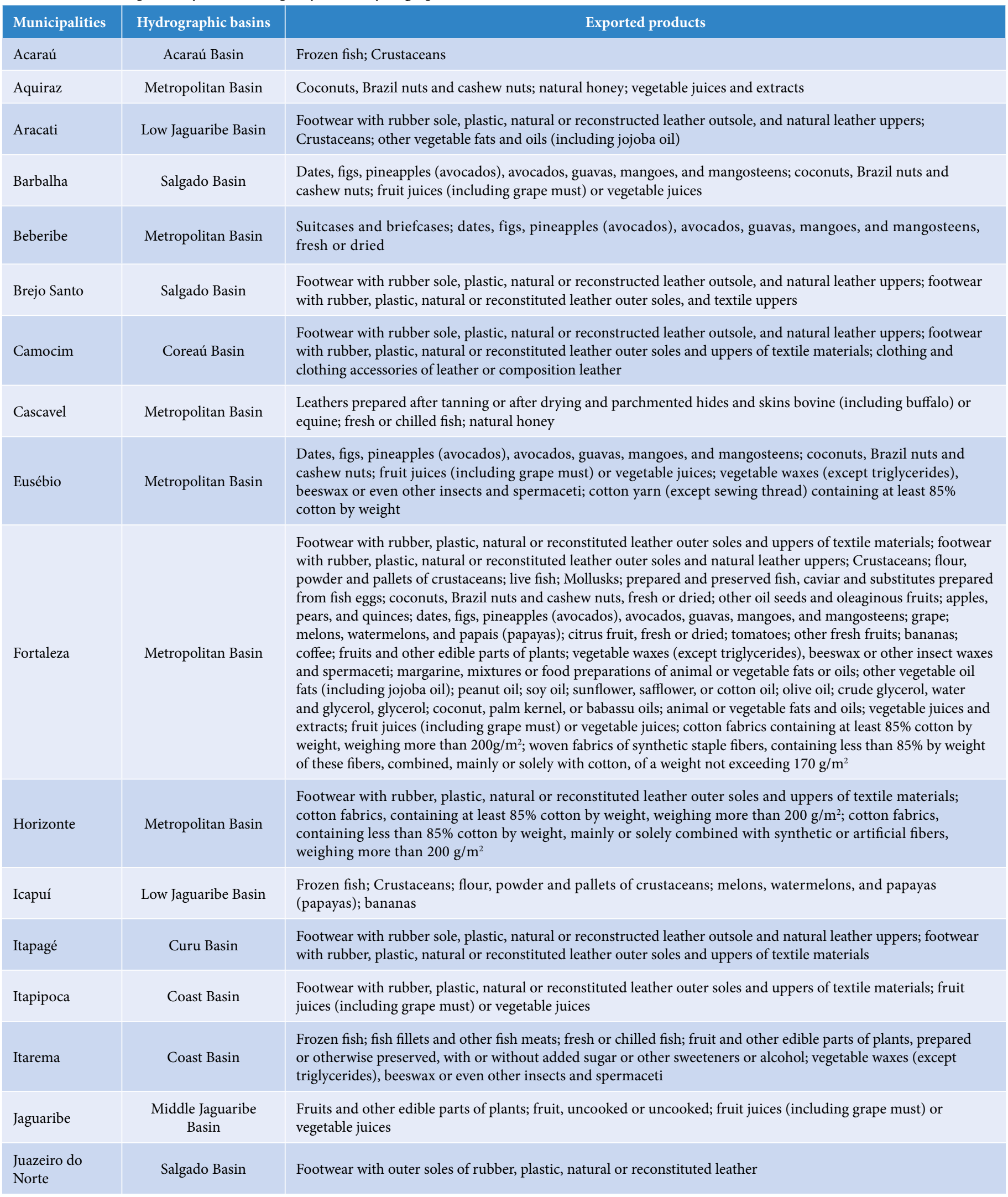


Table 5 - Products exported by each municipality and its hydrographic basins.

\begin{tabular}{|c|c|c|}
\hline Municipalities & Hydrographic basins & Exported products \\
\hline $\begin{array}{l}\text { Limoeiro do } \\
\text { Norte }\end{array}$ & Low Jaguaribe Basin & Fresh or dried bananas \\
\hline Maracanaú & Metropolitan Basin & $\begin{array}{l}\text { Leathers prepared after tanning or after drying and parchmented hides and skins, of bovine (including buffalo) } \\
\text { or equine; tanned or crusted hides and skins of bovine (including buffalo) or equine animals; vegetable waxes } \\
\text { (except triglycerides), beeswax or even other insects and spermaceti; cotton fabrics, containing at least } 85 \% \text { cotton } \\
\text { by weight, weighing more than } 200 \mathrm{~g} / \mathrm{m}^{2} \text {; cotton fabrics, containing less than } 85 \% \text { cotton by weight, combined, } \\
\text { principally or solely, with synthetic or artificial fibers, weighing more than } 200 \mathrm{~g} / \mathrm{m}^{2} \text {; cotton yarn (except sewing } \\
\text { thread), containing at least } 85 \% \text { cotton by weight }\end{array}$ \\
\hline Maranguape & Metropolitan Basin & $\begin{array}{l}\text { Footwear with rubber, plastic, natural or reconstructed leather outsole and natural leather uppers; footwear with } \\
\text { rubber, plastic, natural or reconstituted leather outer soles and uppers of textile materials; suitcases and briefcases }\end{array}$ \\
\hline Pacajus & Metropolitan Basin & $\begin{array}{l}\text { Coconuts, Brazil nuts and cashew nuts, fresh or dried, even shelled or peeled; other nuts; cotton fabrics, } \\
\text { containing at least } 85 \% \text { cotton by weight, weighing more than } 200 \mathrm{~g} / \mathrm{m}^{2} \text {; cotton fabrics, containing less than } 85 \% \\
\text { cotton by weight, mainly or solely combined with synthetic or artificial fibers, weighing more than } 200 \mathrm{~g} / \mathrm{m}^{2}\end{array}$ \\
\hline Pacatuba & Metropolitan Basin & $\begin{array}{l}\text { Footwear with rubber, plastic, natural or reconstructed leather outsole and natural leather uppers; footwear with } \\
\text { rubber, plastic, natural or reconstituted leather outer soles and textile uppers }\end{array}$ \\
\hline Paraipaba & Curu Basin & Fruit juices (including grape must) or vegetable juices \\
\hline Pereiro & $\begin{array}{l}\text { Middle Jaguaribe } \\
\text { Basin }\end{array}$ & Fruits and other edible parts of plants; fruit juices (including grape must) or vegetable juices \\
\hline Quixeramobim & Banabuiú Basin & $\begin{array}{l}\text { Footwear with rubber, plastic, natural or reconstructed leather outsole and natural leather uppers; footwear with } \\
\text { rubber, plastic, natural or reconstituted leather outer soles and uppers of textile materials; suitcases and briefcases }\end{array}$ \\
\hline Quixeré & Low Jaguaribe Basin & $\begin{array}{l}\text { Footwear with rubber, plastic, natural or reconstituted leather outer soles and uppers of textile materials; other } \\
\text { footwear with outer sole and rubber or plastic upper; melons, watermelons, and papayas (papayas), fresh }\end{array}$ \\
\hline Russas & Low Jaguaribe Basin & Vegetable waxes (except triglycerides), beeswax or even other insects and spermaceti \\
\hline $\begin{array}{l}\text { São Gonçalo do } \\
\text { Amarante }\end{array}$ & Curu Basin & Prepared and preserved fish, caviar and substitutes prepared from fish eggs; frozen, fresh or chilled fish \\
\hline $\begin{array}{l}\text { Senador } \\
\text { Pompeu }\end{array}$ & Banabuiú Basin & $\begin{array}{l}\text { Footwear with rubber, plastic, natural or reconstituted leather outer soles and uppers of textile materials; footwear } \\
\text { with rubber, plastic, natural or reconstructed leather outer sole and natural leather uppers }\end{array}$ \\
\hline Sobral & Acaraú Basin & $\begin{array}{l}\text { Footwear with rubber, plastic, natural or reconstituted leather outer soles and uppers of textile materials; suitcases } \\
\text { and briefcases }\end{array}$ \\
\hline Ubajara & Coreaú Basin & $\begin{array}{l}\text { Fruit juices (including grape must) or vegetable juices; fruits, uncooked or cooked in water or steam, frozen, } \\
\text { whether or not containing added sugar or other sweetening matter }\end{array}$ \\
\hline Uruburetama & Coast Basin & $\begin{array}{l}\text { Footwear with rubber, plastic, natural or reconstituted leather outer soles and uppers of textile materials; footwear } \\
\text { with rubber, plastic, natural or reconstructed leather outer sole and natural leather uppers }\end{array}$ \\
\hline
\end{tabular}

Source: Brasil (2020).

1 , corresponding to $100 \%$. To use the AHP method, at least two alternatives are necessary, in order to select the most sustainable category for export (Table 8).

The percentage table supported the creation of a histogram to which it is possible to analyze the consistency of the results. This type of graphic allows the preview of the distribution of events (Figure 9).

We can observe from this histogram that the decision percentages are well distributed in relation to the cutoff frequencies calculated. However, more decisions were obtained with the smallest cutoff and less with the largest cutoff values. The lower cutoff value having a higher frequency is also due to the fact that most categories for decision had more than two alternatives, so the categories that were not elected as the most sustainable are distributed in the lowest cutoff values (Figure 10).

By changing the cutoff frequencies calculated by the categories of exported products, we obtained the frequency of decisions by category, which is worth mentioning that each city exports more than one product, with 21 municipalities taking part in AHP decision-making.

Replacing the AHP percentage table with the respective WFs of the evaluated products, a histogram was also made to verify the decision 
Table 6 - Categories exported by each municipality.

\begin{tabular}{|c|c|}
\hline Product category & Municipalities \\
\hline Footwear & $\begin{array}{l}\text { Aracati, Brejo Santo, Camocim, Fortaleza, } \\
\text { Horizonte, Itapajé, Itapipoca, Juazeiro } \\
\text { do Norte, Maranguape, Pacatuba, } \\
\text { Quixeramobim, Quixeré, Senador Pompeu, } \\
\text { Sobral, Uburetama }\end{array}$ \\
\hline Leather & $\begin{array}{l}\text { Beberibe, Camocim, Cascavel, Maracanaú, } \\
\text { Maranguape, Quixeramobim, Sobral }\end{array}$ \\
\hline $\begin{array}{l}\text { Fillets or other frozen, } \\
\text { fresh or chilled meat }\end{array}$ & $\begin{array}{l}\text { Acaraú, Aracati, Cascavel, Fortaleza, Icapuí, } \\
\text { Itarema, São Gonçalo do Amarante }\end{array}$ \\
\hline $\begin{array}{l}\text { Fresh or dried fruit and } \\
\text { nuts, fresh or dried }\end{array}$ & $\begin{array}{c}\text { Aquiraz, Barbalha, Beberibe, Eusébio, } \\
\text { Fortaleza, Icapuí, Itarema, Jaguaribe, } \\
\text { Limoeiro do Norte, Pacajus, Pereiro, } \\
\text { Quixeré, Ubajara }\end{array}$ \\
\hline $\begin{array}{l}\text { Other processed animal } \\
\text { or vegetable fats and oils, } \\
\text { waxes, mixtures or non- } \\
\text { food preparations }\end{array}$ & $\begin{array}{l}\text { Aquiraz, Aracati, Cascavel, Eusébio, } \\
\text { Fortaleza, Itarema, Maracanaú, Russas }\end{array}$ \\
\hline Fruit juices and vegetables & $\begin{array}{c}\text { Aquiraz, Aracati, Barbalha, Eusébio, } \\
\text { Fortaleza, Itapipoca, Jaguaribe, Paraipaba, } \\
\text { Pereiro, Ubajara }\end{array}$ \\
\hline $\begin{array}{l}\text { Cotton fabric, screens (not } \\
\text { including tapes or specials) }\end{array}$ & $\begin{array}{c}\text { Eusébio, Fortaleza, Horizonte, Maracanaú, } \\
\text { Pacajus }\end{array}$ \\
\hline
\end{tabular}

Source: Brasil (2020).

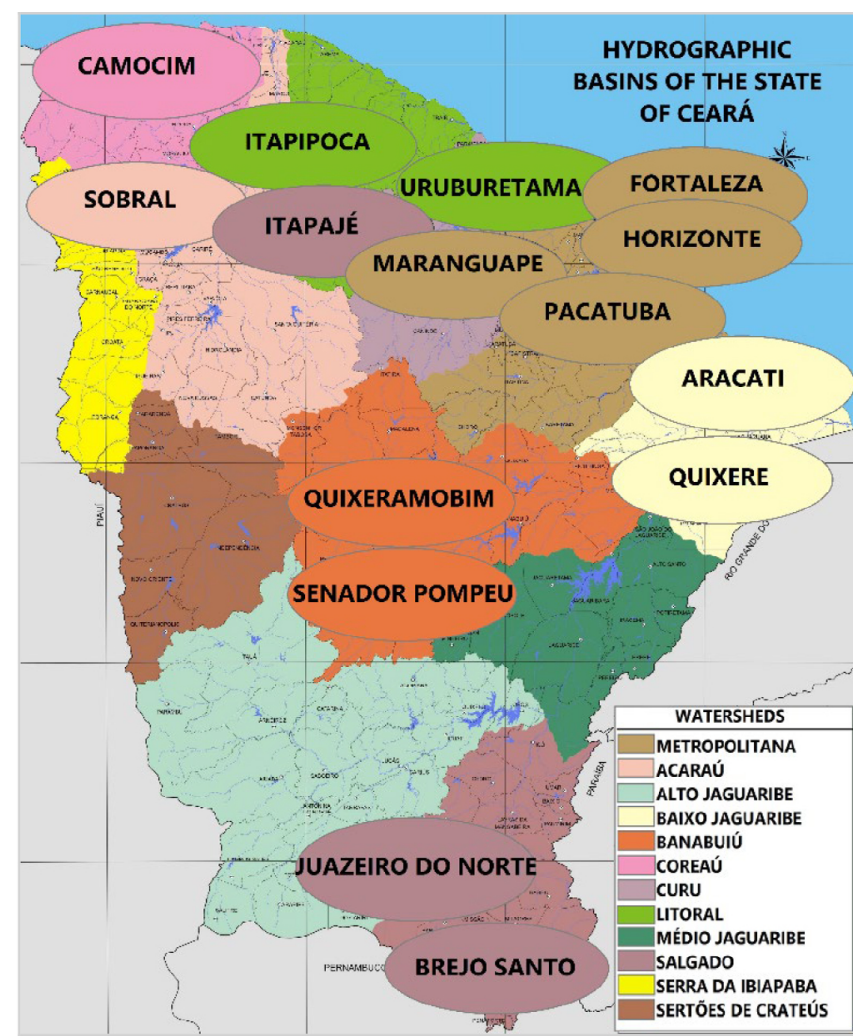

Figure 2 - Map cities and watersheds of the footwear category.

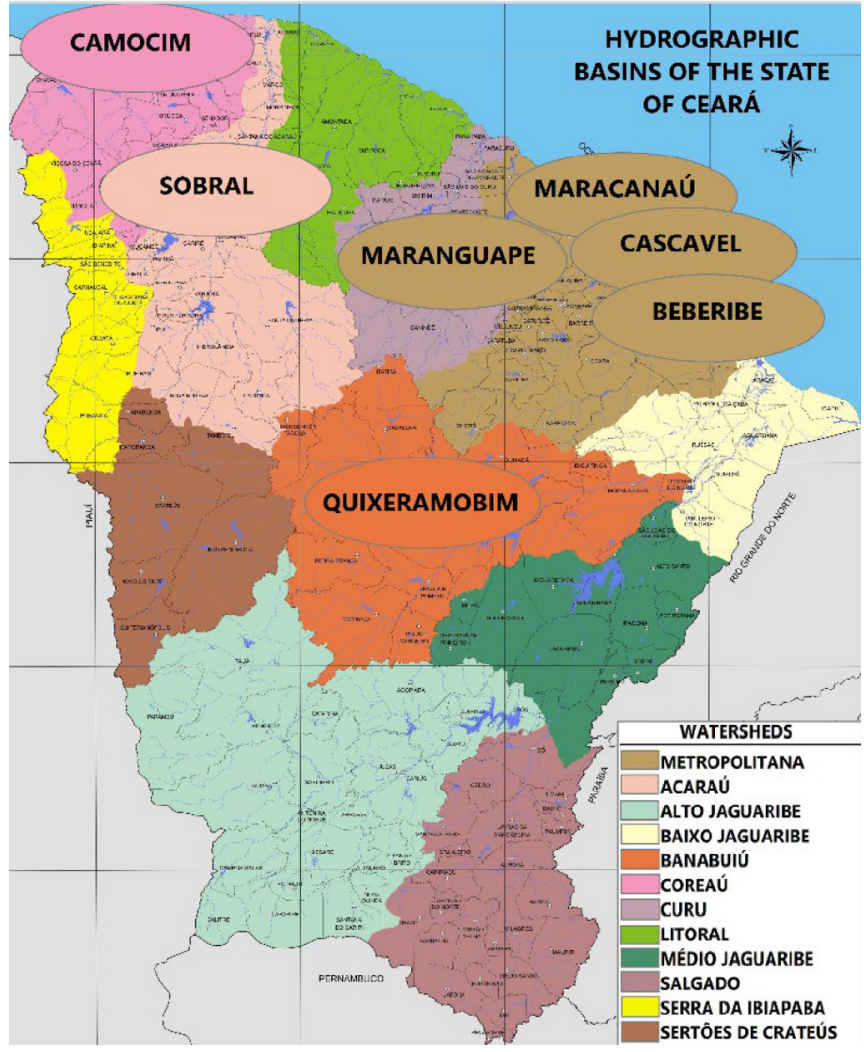

Figure 3 - Map cities and watersheds of the leather category.

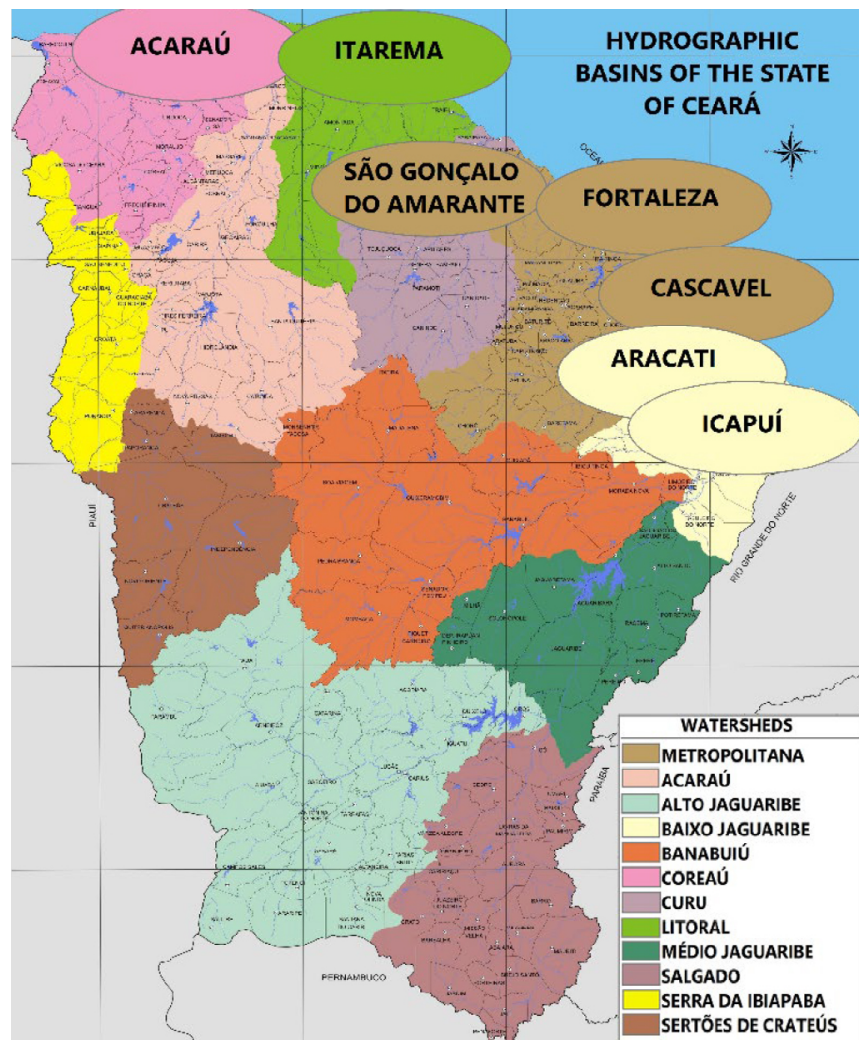

Figure 4 - Map cities and watersheds in the category of fillets and other fish meats. 


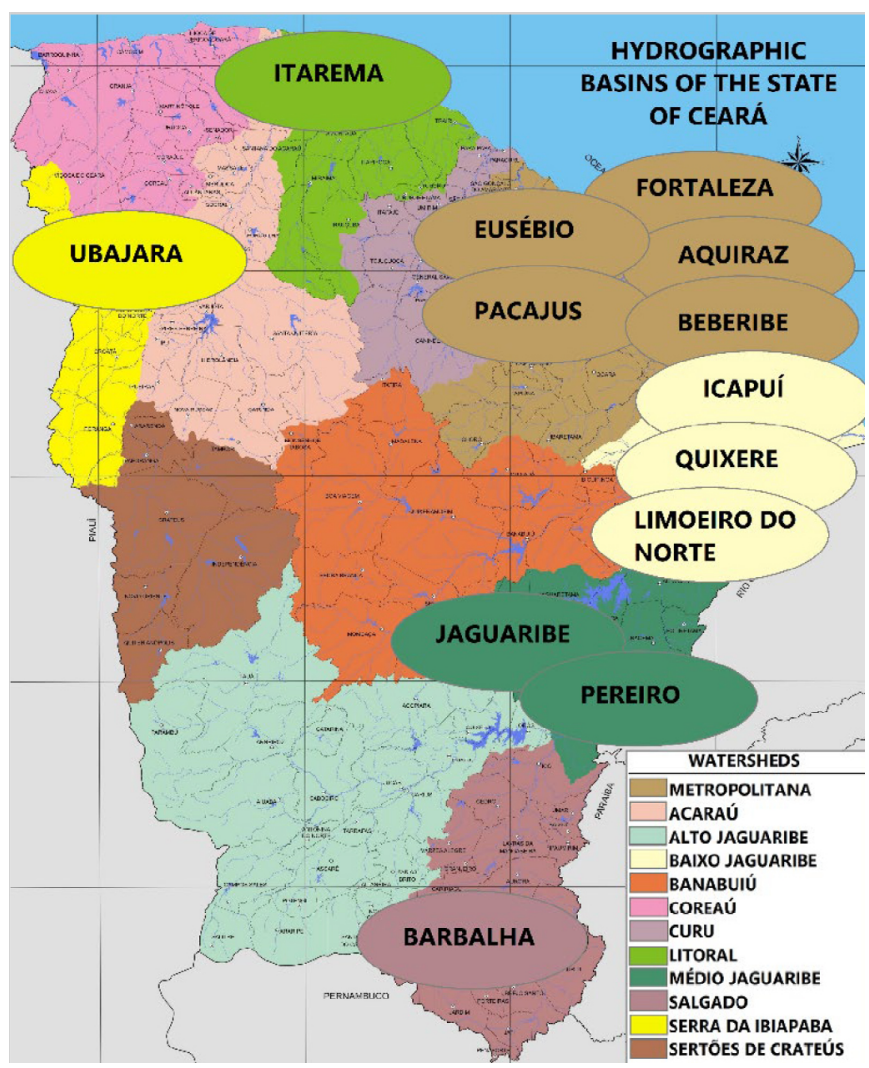

Figure 5 - Map cities and watersheds of the fruit and nut category.

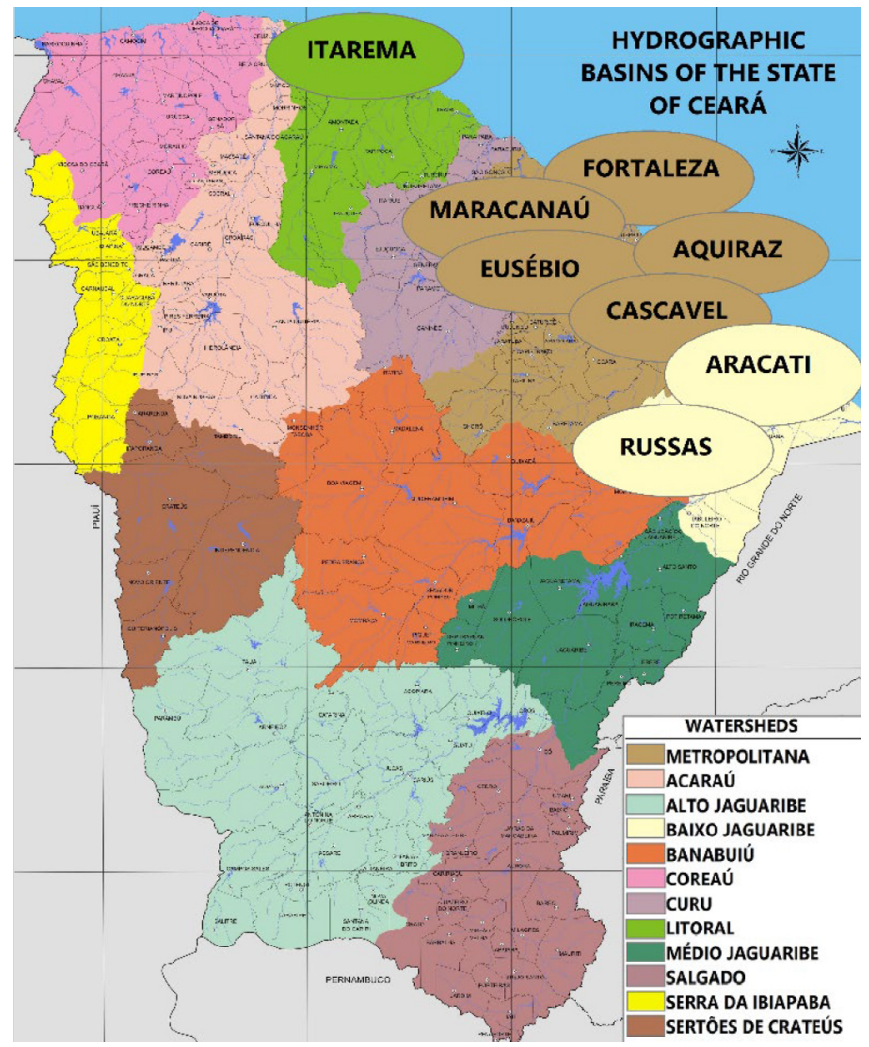

Figure 6 - Map cities and watersheds of the category of other fats and oils.

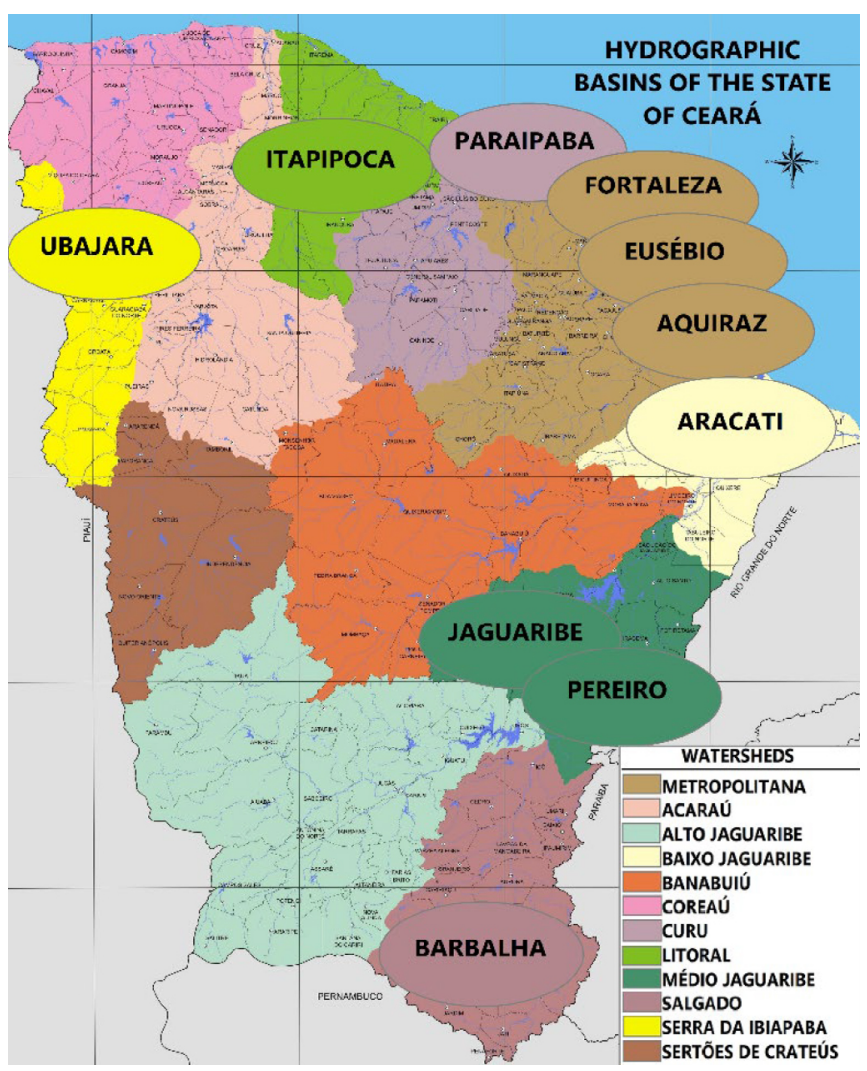

Figure 7 - Map of cities and watersheds in the category of fruit or vegetable juices.

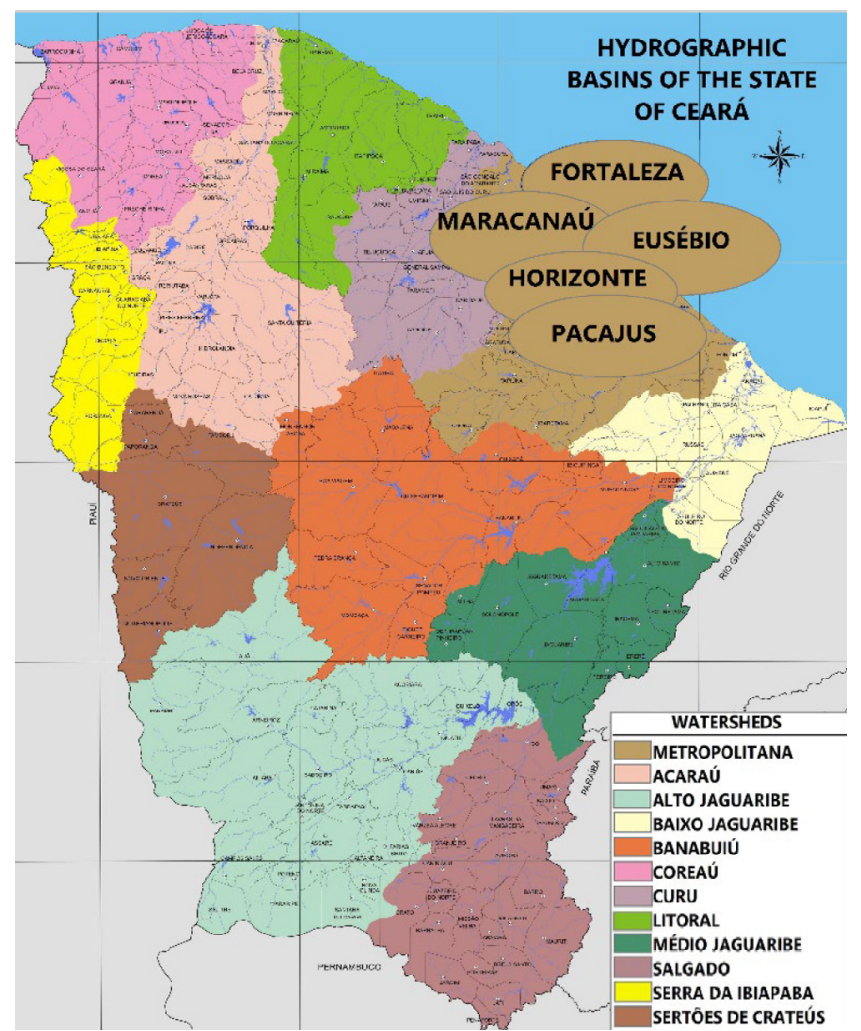

Figure 8 - Map cities and watersheds of the cotton fabric category. 
Table 7 - Criteria admitted for the analytical hierarchy process.

\begin{tabular}{|c|c|c|c|}
\hline Product & Water footprint $\left(\mathrm{m}^{3} / \mathrm{t}\right)$ & Price in MI (US\$) & Tons Ceará \\
\hline Footwear & 18,770 & 236 & $12,681.55$ \\
\hline Leather & 18,770 & 52.3 & $21,327.13$ \\
\hline Fresh or dried fruit and nuts, fresh or dried & $3,500.6$ & 161 & $164,901.38$ \\
\hline $\begin{array}{l}\text { Other processed animal or vegetable fats and oils, waxes, mixtures or non- } \\
\text { food preparations }\end{array}$ & 1,782 & 68.8 & $16,381.92$ \\
\hline Cotton fabric, screens (not including tapes or specials) & More importance & Medium importance & Low importance \\
\hline
\end{tabular}

Source: Hoekstra et al. (2011) and Brasil (2020).

Table 8 - Percentage table for analytical hierarchy process (AHP).

\begin{tabular}{|c|c|c|c|c|c|c|c|}
\hline \multicolumn{8}{|c|}{ FINAL PERCENTAGE TABLE AHP } \\
\hline Cities & Footwear & Leather & Fillets and others Meats & Fruits and Nuts & Other fats & Fruit na Vegetable Juices & Cotton Fabric \\
\hline Aquiraz & $\mathrm{x}$ & $\mathrm{x}$ & $\mathrm{x}$ & 0.3165 & 0.2325 & 0.4499 & $\mathrm{x}$ \\
\hline Barbalha & $\mathrm{x}$ & $\mathrm{x}$ & $\mathrm{x}$ & 0.3862 & $\mathrm{x}$ & 0.6128 & $\mathrm{x}$ \\
\hline Beberibe & $\mathrm{x}$ & 0.3061 & $\mathrm{x}$ & 0.6928 & $\mathrm{x}$ & $\mathrm{x}$ & $\mathrm{x}$ \\
\hline Camocim & 0.5682 & 0.4308 & $\mathrm{x}$ & $\mathrm{x}$ & $\mathrm{x}$ & $\mathrm{x}$ & $\mathrm{x}$ \\
\hline Eusébio & $\mathrm{x}$ & $\mathrm{x}$ & $\mathrm{x}$ & 0.3963 & 0.1392 & 0.0879 & 0.3756 \\
\hline Fortaleza & 0.0783 & $\mathrm{x}$ & 0.0253 & 0.5009 & 0.1187 & 0.2300 & 0.0468 \\
\hline Horizonte & 0.3927 & $\mathrm{x}$ & $\mathrm{x}$ & $\mathrm{x}$ & $\mathrm{x}$ & $\mathrm{x}$ & 0.6063 \\
\hline Icapuí & $\mathrm{x}$ & $\mathrm{x}$ & 0.1421 & 0.8569 & $\mathrm{x}$ & $\mathrm{x}$ & $\mathrm{x}$ \\
\hline Itapipoca & 0.3079 & $\mathrm{x}$ & $\mathrm{x}$ & $\mathrm{x}$ & $\mathrm{x}$ & 0.6911 & $\mathrm{x}$ \\
\hline Maranguape & 0.6323 & 0.3667 & $\mathrm{x}$ & $\mathrm{x}$ & $\mathrm{x}$ & $\mathrm{x}$ & $\mathrm{x}$ \\
\hline Pacajus & $\mathrm{x}$ & $\mathrm{x}$ & $\mathrm{x}$ & 0.8540 & $\mathrm{x}$ & $\mathrm{x}$ & 0.1449 \\
\hline Pereiro & $\mathrm{x}$ & $\mathrm{x}$ & $\mathrm{x}$ & 0.4259 & $\mathrm{x}$ & $\mathrm{x}$ & $\mathrm{x}$ \\
\hline Quixeramobim & $\mathrm{x}$ & $\mathrm{x}$ & $\mathrm{x}$ & $\mathrm{x}$ & $\mathrm{x}$ & 0.5730 & $\mathrm{x}$ \\
\hline Quixeré & 0.1331 & $\mathrm{x}$ & $\mathrm{x}$ & 0.8658 & $\mathrm{x}$ & $\mathrm{x}$ & $\mathrm{x}$ \\
\hline Sobral & 0.6323 & 0.3667 & $\mathrm{x}$ & $\mathrm{x}$ & $\mathrm{x}$ & $\mathrm{x}$ & $\mathrm{x}$ \\
\hline Ubajara & $\mathrm{x}$ & $\mathrm{x}$ & $\mathrm{x}$ & 0.3882 & $\mathrm{x}$ & 0.6108 & $\mathrm{x}$ \\
\hline
\end{tabular}

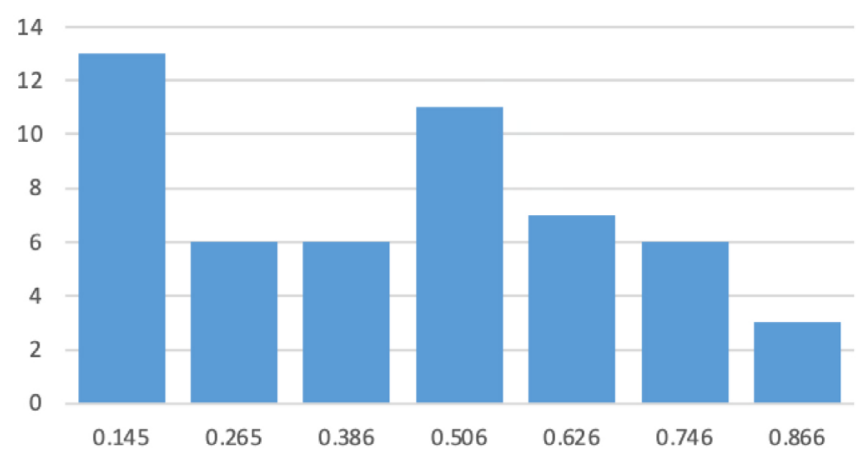

Figure 9 - Histogram of analytical hierarchy process percentages by cutoff frequency.

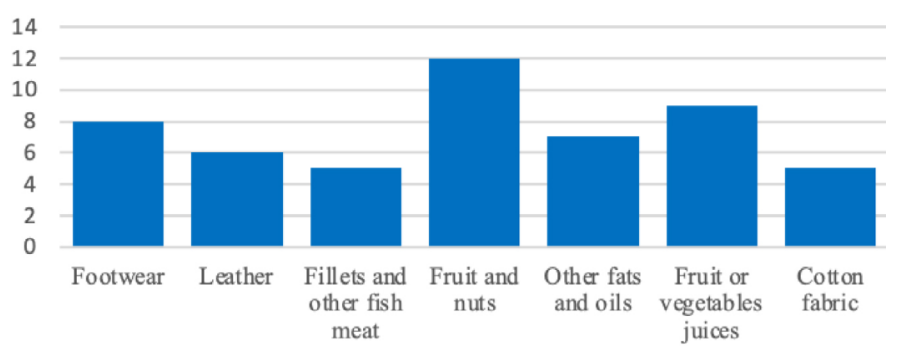

Figure 10 - Histogram of analytical hierarchy process decision percentages by product category. 
percentage of the AHP and the WFs of the classes by cutting section of the chosen products (Figure 11).

As previously done, the cutoff frequencies calculated were changed by the WFs of the seven product categories, with the intention of visualizing the distribution of the results of decisions by WF (Figure 12).

The WF of the footwear was admitted to be the same as that of the leather category. Here we are analyzing the cities that entered the AHP decision process, and not the method decision; therefore, the WF that obtained a higher frequency was the leather and footwear sector.

Table 9 summarizes the product category for export selected by the AHP decision-making method for each exporting municipality, including those that did not participate in the decision-making, being the only product that exports the most sustainable.

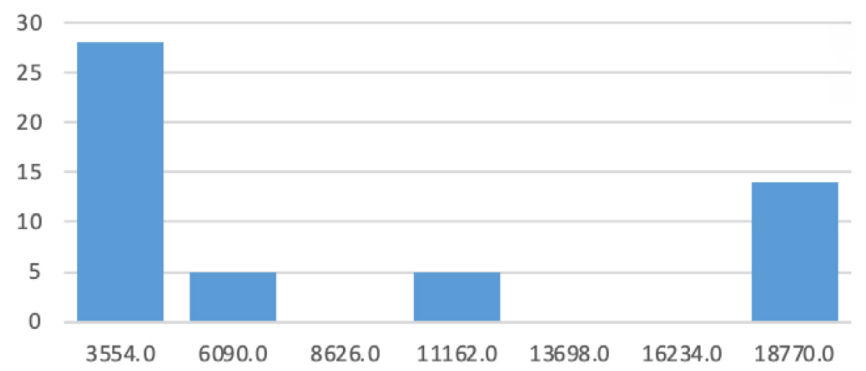

Figure 11 - Histogram of analytical hierarchy process and water footprint decision percentages.

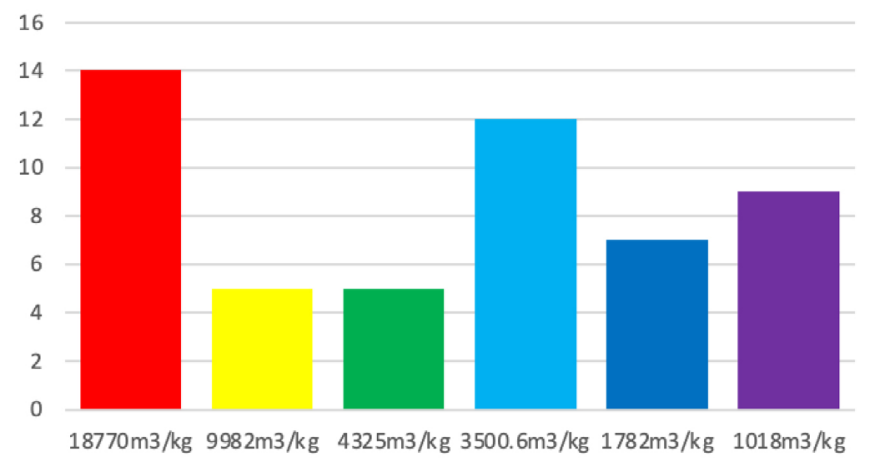

$:$ Footwear and leather
$:$ Cotton fabric
$:$ Fillets and other fish meats
$:$ Fruits and nuts
$:$ Other fat and oils
$:$ Fruit or vegetable juice

Figure 12 - Analytical hierarchy process decision percentages by water footprint.
Table 9 - Analysis of the most sustainable product for each city to export.

\begin{tabular}{|c|c|}
\hline City & More sustainable product \\
\hline Acaraú & Fillets or other frozen, fresh or chilled meat \\
\hline Aquiraz & Fruit or vegetable juices \\
\hline Aracati & Fruit or vegetable juices \\
\hline Barbalha & Fruit or vegetable juices \\
\hline Beberibe & Fresh or dried fruit and nuts \\
\hline Brejo Santo & Footwear \\
\hline Camocim & Footwear \\
\hline Cascavel & $\begin{array}{l}\text { Other processed animal or vegetable fats } \\
\text { and oils, waxes, mixtures or non-food } \\
\text { preparations }\end{array}$ \\
\hline Eusébio & Fruit or vegetable juices \\
\hline Fortaleza & Fruit or vegetable juices \\
\hline Horizonte & $\begin{array}{c}\text { Cotton fabric, screens (not including tapes } \\
\text { or specials) }\end{array}$ \\
\hline Icapuí & Fresh or dried fruit and nuts \\
\hline Itapagé & Footwear \\
\hline Itapipoca & Fruit or vegetable juices \\
\hline Itarema & $\begin{array}{l}\text { Other processed animal or vegetable fats } \\
\text { and oils, waxes, mixtures or non-food } \\
\text { preparations }\end{array}$ \\
\hline Jaguaribe & Fruit or vegetable juices \\
\hline Juazeiro do Norte & Footwear \\
\hline Maracanaú & $\begin{array}{l}\text { Other processed animal or vegetable fats and } \\
\text { oils, waxes, mixtures or non-food preparations }\end{array}$ \\
\hline Maranguape & Footwear \\
\hline Pacajus & Fresh or dried fruit and nuts \\
\hline Pacatuba & Footwear \\
\hline Paraipaba & Fruit or vegetable juices \\
\hline Pereiro & Fruit or vegetable juices \\
\hline Quixeramobim & Footwear \\
\hline Quixeré & Fresh or dried fruit and nuts \\
\hline Russas & $\begin{array}{l}\text { Other processed animal or vegetable fats } \\
\text { and oils, waxes, mixtures or non-food } \\
\text { preparations }\end{array}$ \\
\hline São Gonçalo do Amarante & Fillets or other frozen, fresh or chilled meat \\
\hline Senador Pompeu & Footwear \\
\hline Sobral & Footwear \\
\hline Ubajara & Fruit or vegetable juices \\
\hline Uruburetama & Footwear \\
\hline
\end{tabular}


The result chose, through the objective "more sustainable product," the alternative that is more consistent with the criteria and the importance attributed.

Of the 32 cities in the state of Ceará that export products of agricultural origin, 11 use the reservoirs of the Metropolitan Hydrographic Basin, followed by the Low Jaguaribe Basin with 5, Coast Basin with 4, and Curu and Salgado Basins with 3; Acaraú Basins, Banabuiú, and Middle Jaguaribe with 2 municipalities and Ibiapaba Hill and Coreaú Basin with 1. From this fact, we observe that the water potential of Ceará is not used as it should, as we only use 10 of the 12 hydrographic basins existing in the state and the Metropolitan Basin is the most required and it has the need to supply according to IBGE (2019) more than $4,074,730$ inhabitants of the metropolitan region of Fortaleza (Figure 13).

This study focusing on the current debate on the local dimension in water resource governance aims to analyze empirical cases of water management in the Brazilian semi-arid, based on the performance of the intermunicipal consortia and the São Francisco River Basin committee. Abers and Keck (2013) argued that the institutionalization of river basin committees has yielded very heterogeneous results, particularly in relation to the participation of municipalities. Thus, throughout the research, it was seen that, in several surveys, the cases of intermu-

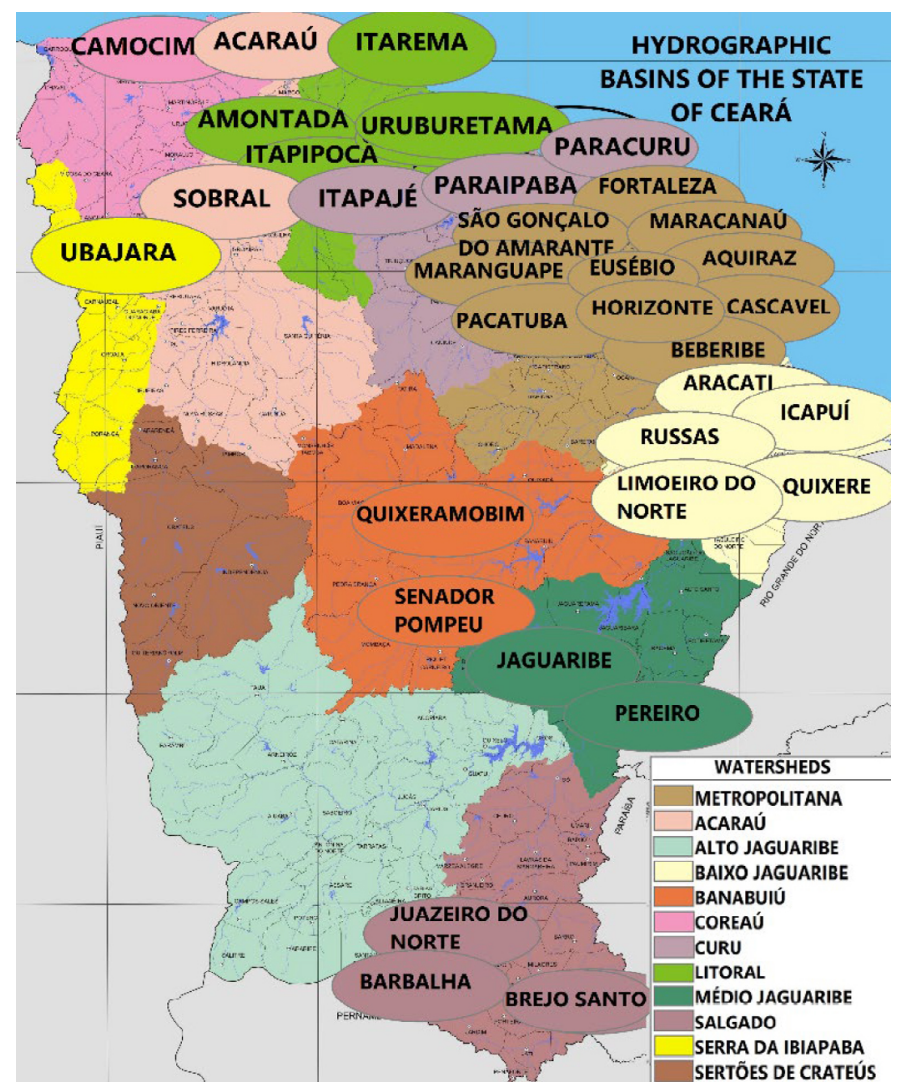

Figure 13 - Map exporting cities of the state of Ceará in 2019 and their hydrographic basins. nicipal consortia and river-based committee proved to be opportunities for greater visibility is the action of the local participants. It was found that there is a need for strategies that enable a well-defined organization of cooperation and perception at local levels among the new governance arrangements (Kasahara et al., 2020).

\section{Conclusions}

The category "fruit or vegetable juices" was deferred by the decision-making method as the most sustainable by the municipalities in the state of Ceara that export to other countries. With the aid of the histograms, it was possible to analyze that the distribution of cutoff values in relation to decision-making proved to be well distributed, although there were few decisions by product classes that obtained about $80 \%$ assertiveness in the results. The second highest percentage is of medium cutoff value, showing that the second majority of decisions were elected with $50 \%$ assertiveness.

The histogram of the AHP decision percentage and WF has the cutoff frequency calculated by maximum and minimum between the WFs of each product that entered the decision-making process. Thus, Figure 11 shows that the majority of the products chosen or not have the lowest footprints of the study is the most important issue, taking into account the discrepancy between the values of the smallest and largest WF.

The study found that the footwear sector has the greatest economic importance in the state, being the category that exports the most, with 15 cities, and with the highest export price than the other classes. However, due to its high WF, it cannot be elected as the most sustainable product category. Therefore, the most sustainable exported product category chosen is "fruit or vegetable juices," as it is the one that best suits the requirements of WF, price, and volume.

The basin committees in the state of Ceará reflect the same reality observed in the studies that point to an inadequacy of the water framing instrument, making it difficult to control water quality in the gray WF. This scenario of framing is not viable in the Ceará basins because the rivers are intermittent and part of the year is dry. Another important fact is that the need to assume the WF as an instrument for the management of water resources is suggested in order to better control this quality in the face of the difficulties encountered in the basin committees.

When analyzing the water potential of Ceará, we see that there is still a lot to explore as the state's water requirement for the production of goods to be exported is concentrated around $32 \%$ only in the Metropolitan Basin. The requirement for water by only one basin can lead to very low levels of reservoirs that may not support the current demand in the future. The other river basins are underused and study with fair logistics is recommended for better management and use of water resources in the state of Ceará, or even create forms of government incentives so that companies further away from the capital can also produce and sell their products at international level. 


\section{Contribution of authors:}

Leite, I.S.: Conceptualization, Methodology, Validation, Formal analysis, Investigation, Resources, Writing - original draft, Writing - review \& editing, Data curation. Sabiá, R.J.: Conceptualization, Methodology, Validation, Formal analysis, Investigation, Visualization, Resources, Supervision, Project administration. Matos, A.P.: Formal analysis, Investigation, Validation, Visualization, Data curation. Silva, C.C.: Methodology, Formal analysis, Investigation, Validation.

\section{References}

Abers, R. N.; Keck, M. E., 2013. Practical authority: agency and institutional change in Brazilian water politics. Oxford and New York, Oxford University Press.

Agência Nacional de Águas (ANA), 2018. Plano Estadual dos Recursos Hídricos (Accessed September 28, 2020) at: https://dadosabertos.ana.gov.br/ datasets/d5c8d1093d0a44d8aa2e36d6d00f4422_0.

Almeida, A., 2013. Processos de decisão nas organizações: construindo modelos de decisão multicritério. Atlas, São Paulo.

Barker, T.; Zabinsky, Z., 2010. Designing for recovery-A solid reverse supply chain can help you recover, renew, recycle. Industrial Engineer, v. 42, (4), 38.

Barreto, J. F.; Neto, J. D.; Farias, S. A. R., 2010. Avaliação socioeconômica e hídrica dos municípios da sub-bacia hidrográfica do rio Taperoá, PB. Qualit@s Revista Eletrônica, v. 9, (1), 1-13. http://dx.doi.org/10.18391/ qualitas.v9i1.585.

Brasil. Conselho Nacional do Meio Ambiente - CONAMA. 2005. Resolução $\mathrm{n}^{\circ}$ 357, de 17 de março de 2005 do Conselho Nacional do Meio AmbienteCONAMA. Dispõe sobre a classificação dos corpos de água. Diário Oficial da União.

Brasil. Ministério da Indústria, Comércio Exterior e Serviços (MDIC), 2020. Comex Vis: Visualizações de Comércio Exterior (Accessed September 12, 2020.) at: http://www.mdic.gov.br/comercio-exterior/estatisticas-de-comercioexterior/comex-vis.

Companhia de Gestão dos Recursos Hídricos (COGERH), 2018. Bacias hidrográficas (Accessed July 20, 2020) at: https://portal.cogerh.com.br.

Falkenmark, M.; Molden, D., 2008. Wake up to realities of river basin closure. International Journal of Water Resources Development, v. 24, (2), p. 201-215. http://dx.doi.org/10.1080/07900620701723570.

Fiel, A.; Strasburg, V.; Spilki, F., 2017. Variáveis intervenientes na existência de comitês de bacias hidrográficas no Brasil. Ambiente \& Água (Online), v. 12, (2), 340-350. https://doi.org/10.4136/ambi-agua.1828.

Fundação Cearense de Meteorologia e Recursos Hídricos (FUNCEME), 2019. Portal Hidrológico do Ceará - Reservatórios (Accessed July 16, 2020.) at: http://www.funceme.br.

Guimarães, P.; Xavier, Y., 2008. A regulamentação da água virtual nos sistemas ambientais. Ambiente e Sociedade, p. 702-717.

Hoekstra, A.; Chapagain, A., 2007. The water footprints of Morocco and the Netherlands: Global water use as a result of domestic consumption of agricultural commodities. Ecological Economics, v. 64, (1), 143-151. https:// doi.org/10.1016/j.ecolecon.2007.02.023.

Hoekstra, A.; Chapagain, A.; Aldaya, M.; Mekonnen, M., 2011. Water footprint assessment manual: setting the global standard. Earthscan, London.
Instituto Brasileiro de Geografia e Estatística (IBGE), 2019. Cidades e Estados. (Accessed February 20, 2020) at: https://www.ibge.gov.br/cidades-e-estados/ce.html.

Instituto de Pesquisa e Estratégia Econômica do Ceará (IPECE), 2010. Ceará em Números (Accessed January 4, 2020.) at: https://www.ceara.gov. br/2010/03/13/ceara-em-numeros/.

Kaplowitz, M. D.; Witter, S. G., 2008. Agricultural and residential stakeholder input for watershed management in a mid-Michigan watershed. Landscape and Urban Planning, v. 84, (1), p. 20-27. http://dx.doi.org/10.1016/j. landurbplan.2007.06.004.

Kasahara, Y.; Sobral, M.; Melo, M., 2020. A dimensão local na governança dos recursos hídricos: a experiência de consórcios e comissões intermunicipais de bacias de rio. Revista Brasileira de Ciências Ambientais (Online), v. 55, (3), 282-297. https://doi.org/10.5327/Z2176-94782020071.

Kurokawa, E.; Bornia, A., 2002. Utilizando o histograma como uma ferramenta estatística de análise da produção de água tratada de Goiânia. XXVII Congresso Interamericano de Ingeniaría Sanitaria y Ambiental, Cancun, México.

Lopes, P. A., 1999. Probabilidades \& estatística. R\&A, Rio de Janeiro, 174 pp.

Mahmoud, M. I.; Gupta, H. V.; Rajagopal, S., 2011. Scenario development for water resources planning and watershed management: Methodology and semi-arid region case study. Environmental Modelling \& Software, v. 26, (7), p. 873-885. http://dx.doi.org/10.1016/j.envsoft.2011.02.003.

Porto, R. L. L.; Filho, K. Z.; Marcellini, S. S., 1999. Escoamento superficial: análise do hidrograma. Departamento de Engenharia Hidráulica e Sanitária, São Paulo.

Saaty, T., 1977. A scaling method for priorities in hierarchical structures. Journal of Mathematical Psychology, v. 15, (3), 234-281. https://doi. org/10.1016/0022-2496(77)90033-5.

Silva, F. D.; Salgado, M. S.; Silva S. M., 2015. Desenvolvimento de projetos sustentáveis usando a plataforma BIM: estudo de caso na cidade do Rio de Janeiro. Latin American and European Conference on Sustainable Buildings EURO ELECS, Guimarães, Portugal, v. 2, 1513-1522.

Souza, V.; Pizella, D., 2021. O quadro brasileiro de água doce superficial em rios dominados por sindicatos: desafios e perspectivas para a gestão da qualidade da água. Revista Brasileira de Ciências Ambientais (Online), v. 56, (1), 1-15. https://doi.org/10.5327/Z2176-947820200707.

Tramarico, C.; Salomon, V.; Marins, F.; Muniz Jr., J., 2012. Modelagem com AHP e BOCR para a seleção de prestadores de serviços logísticos. Pesquisa Operacional para o Desenvolvimento, v. 4, (2), 139-159.

Vargas, R., 2010. Utilizando a programação multi-critério (Analytic Hierarchy Process - AHP) para selecionar e priorizar projetos na gestão de portfólio. PMI Global Congress, Washington, D.C. 